\title{
A közérdekü munka szerepe a börtönnépesség csökkentésében: a finn tapasztalatok
}

\author{
büntetôpolitika - büntetés - alternatív büntetés - közérdekű munka - \\ börtönnépesség - Finnország
}

A 21. század úgy tünik, hogy a büntetési nemek évszázada a büntetőjogban. Ahogyan a 19. század büntetőjogi gondolkodása a dogmatika köré csoportosult, annyira domináns kérdés ma - a folyamatosan változó jogi környezetben - a büntetési nemek kérdése. Az aktuális büntetőpolitikai törekvések nagy része a szabadságvesztés alternatíváinak kereséséröl szól. Az elmúlt évszázadban a szabadságvesztés dominanciája megkérdőjelezhetetlen volt. ${ }^{1}$ A szabadságvesztés volt az úgynevezett jó büntetés, a deklarált büntetési célok is leginkább ehhez a büntetéshez illeszkednek. $^{2}$

Napjainkban azonban a szabadságelvonással járó büntetésekkel, illetve azok nagyarányú alkalmazásával szemben, azok közismert hátrányai egyértelmú kétségeket ébresztenek. Egyrészröl a szabadságelvonással járó büntetések költséges volta indokolja a büntetési rendszerben való csökkenő jelentőségüket. Másrészt megingott a hit abban, hogy a szabadságvesztés-büntetés alkalmas arra, hogy elrettentsen az újabb bủncselekmény elkövetésétöl. Ez a tény szintén igazolja az alternatív szankciók folyamatos keresését. Különösen fontos kérdés ez akkor, amikor Európa több országában is probléma, hogy a túlzsúfolt börtönök ${ }^{3}$ és a rossz fogvatartási körülmények miatt az elmarasztaló strasbourgi ítéletek jelentős kártérítések megfizetésére kötelezik az államokat, a kínzás vagy az embertelen, megalázó bánásmód tilalmának megsértése miatt. ${ }^{4}$

A strasbourgi ítéletek nyomán a fogvatartottak részére fizetendő kártérítések természetesen nem, illetve nem csak újabb büntetés-végrehajtási intézetek megépíté-

* Dr. Sipos Ferenc egyetemi tanársegéd, Debreceni Egyetem Állam- és Jogtudományi Kar Büntetőjogi és Kriminológiai Tanszék, siposft@freemail.hu

GYöRGYı Kálmán: Büntetések és intézkedések. Közgazdasági és Jogi Könyvkiadó, Budapest, 1984, 260.

GYöRGYI: i. m., 190.

3 NAGY Ferenc: Az európai börtönnépességröl. Börtönügyi Szemle, 2016/3, 11-27.

4 Hazánkat érintően lásd Varga és mások kontra Magyarország ügy, 2015. március 10-i itélet (ügyszámok: 14097/12, 45135/12, 73712/12, 34001/13, 44055/13 and 64586/13). A büntetés-végrehajtási intézeteink túlzsúfoltságával kapcsolatos strasbourgi gyakorlatot és a pilotítéletek részletes kifejtését lásd SzEMESI Sándor: Sok (jó) ember kis helyen? A magyar fegyintézetek zsúfoltságával kapcsolatos kérdések az Emberi Jogok Európai Bírósága gyakorlatában. Büntetőjogi Szemle, 2014/2, 85-88. A túlzsúfoltság nemzetközi összehasonlításáról lásd bővebben NAGY Ferenc-JuHÁsz Zsuzsanna: A fogvatartotti rátáról nemzetközi összehasonlításban. Börtönügyi Szemle, 2010/3, 1-12. 
sével, továbbá a meglévők kibővítésével kerülhetők el. ${ }^{5}$ Hiszen ez a stratégia csak rövid távú megoldást szülhet, ám a mélyen gyökerező problémákra nem ad választ. A börtönpopuláció csökkentésének egyik lehetséges eszköze az, ha a bíróságok kevesebb végrehajtandó szabadságvesztés büntetést szabnak ki.

A büntetöjogi büntetések, a büntetési nemek rendszere azonban zárt rendszer. Zárt, mert jogok korlátozásával jár, $s$ a jogok száma véges, és vannak ugyanakkor jogok, amelyek a szélesedő alapvető emberi jogokra tekintettel nem vagy csak szigorú garanciális elvekkel összhangban korlátozhatók. Több nemzetközi dokumentum a humanitás jegyében tovább korlátozza a kiszabható büntetések lajstromát.

Ugyanakkor azt kell mondanunk, hogy az alternatív büntetések hatékonysága nem a rendelkezésre álló megoldások széles és aprólékosan szabályozott skálájától függ. Ismerünk olyan európai államokat, ahol szinte már kazuisztikus az alternatív szankciók szabályozása, a jogalkotó a bíró számára az alternatív szankciók viszonylag széles skáláját kínálja, melyek végrehajtási szabályai részleteiben is kidolgozottak, ennek ellenére nagyon alacsony az alternatív szankciók alkalmazási gyakorisága. Ilyen például Belgium és föként Franciaország.

Ugyanakkor ennek ellentéteként említhető olyan állam is, ahol a bíró rendelkezésére álló szankciók lajstroma meglehetősen szük körünek tủnik, az alternatív szankciók alkalmazási számaránya mégis sokkal magasabb és a gyakorlatban a jogintézmények hatékonyan müködnek. Például a svéd büntető törvénykönyvben mindössze két büntetés található, a szabadságvesztés ${ }^{6}$ és a pénzbüntetés. ${ }^{7} \mathrm{Az}$ összes többi büntetés, így a közérdekủ munka is a szabadságvesztés alternatívájaként van jelen, és csak akkor használható, ha az adott tényálláshoz előirt büntetés szabadságvesztés a büntető törvénykönyv különös részében. 2012-ben Svédországban egy parlamenti bizottság aggályosnak is találta ezt az állapotot. A megfogalmazott kritika szerint tarthatatlan, hogy a pénzbüntetést követően leggyakrabban alkalmazott büntetés nincs a Btk.-ban részleteiben szabályozva, és használatának módja jórészt a bíróságok mérlegelésétöl és a végrehajtó szervektől függ, de a mai napig ezt a felvetést tettek nem követték. ${ }^{8}$

Finnország nagyszerủ példája annak, hogy egy helyes, jól átgondolt büntetőpolitika alkalmazása valóban képes megoldani a túlzsúfolt büntetés-végrehajtási intézetek problémáját. A finn eredmények - amint azt látni fogjuk - önmagukért beszélnek. Ennek a jól átgondolt büntetőpolitikának egy fontos része volt Finnországban a közérdekủ munka bevezetése. Tanulmányomban a finn közérdekủ munkára koncentrálva mutatom be, hogyan oldotta meg Finnország a börtönei túlzsúfoltságának problémáját, és hogyan lehet valódi alternatívája a közérdekủ munka a végrehajtandó szabadságvesztésnek. Célom tehát, hogy egy olyan példát ismertessek, amely a magyar szabályozás továbbfejlesztésében ismert és rejtett hibáinak feltárásában is segíthet.

5 Lásd a Belügyminisztérium felhívását önkormányzati tulajdonú, beépítésre szánt terület térítésmentes felajánlására, http://www.kormany.hu/download/e/5a/30000/FELHÍVÁS ingatlan felajánlásra.pdf (2017. 07. 05.).

Svéd Btk. 26. fejezet.

Svéd Btk. 25. fejezet.

8 SVENSSON, Kerstin: Philanthropy, Welfare State and Managerial Treatment: Three Phases of Community Punishment in Sweden. In: Robinson, Gwen-McNeill, Fergus (eds.): Community Punishment. European Perspectives. Routledge, London-New York, 2015, 223. 


\section{A közérdekű munkáról}

Az 1970-es évektöl kezdődően felerősödtek azon kriminálpolitikai törekvések, melyek a szabadságvesztés-büntetés ultima ratio jellegét hirdették, és a szabadságvesztést helyettesítő büntetések lehetőségeit kezdték kutatni.

Nem véletlen, hogy éppen ekkor, hiszen ebben az időszakban egyértelmüen megfigyelhető Európa legtöbb országában a börtönpopuláció nagymértékü növekedése. ${ }^{9} \mathrm{Az}$ alternatív szankciók bevezetésével elsőként a rövid tartamú szabadságvesztések kiváltása volt a cél. Ekkor jelent meg a közérdekű munka, és értékelődött fel a feltételes elítélés, különösen a felfüggesztett szabadságvesztés. Ezek az új szankciók kettős célt követtek: egyes formáik a rehabilitációra, míg mások a költséghatékonyságra fókuszáltak. ${ }^{10}$

Az alternatív szankciók sorában tehát a közérdekủ munka ma már klasszikusnak számító büntetés, hiszen szinte az elsők között jelent meg a büntetőjogokban. A közérdekủ munka azonban nem európai találmány, ugyanis 1966-ban az Egyesült Államokban, Kalifornia államban, Alameda megyében alkalmazták először mint alternatív büntetést olyan női elkövetőkkel szemben, akik közlekedési bűncselekmények miatt álltak a bíróság elött, és vagyoni-jövedelmi viszonyaik miatt a pénzbüntetést elöreláthatóan nem lettek volna képesek megfizetni. ${ }^{11} \mathrm{~A}$ kezdeti sikereknek és a programot kísérő nagy figyelemnek köszönhetően gyorsan elterjedt, és a 70-es évektől több száz közérdekűmunka-büntetés program indult útjára az Egyesült Államokban.

A közérdekủ munka európai pályafutása Angliában és Walesben kezdődött. ${ }^{12} \mathrm{Az}$ 1970-es években az amerikai példa nyomán kísérleti jelleggel indították útjára elöször mindössze hat angliai körzetben. ${ }^{13} \mathrm{Az}$ angliai és walesi kedvező tapasztalatok napvilágra kerülése után gyorsan elterjedt a kontinensen - az adott államok szük-

9 NAGY Ferenc: Az európai uniós országok fogvatartotti rátájának alakulásáról. Börtönügyi Szemle, 2005/3, 81.

10 Lásd részletesen Kerezsı Klára: A közösségi büntetések. In: Borbíró Andrea-Kiss Anna-Velez Edit-Garami Lajos (szerk): A kriminálpolitika és a társadalmi bűnmegelőzés kézikönyve II. Igazságügyi és Rendészeti Minisztérium, Budapest, 2009, 171.

11 Miller, Wilbur R. (ed.): The Social History of Crime and Punishment in America - An Encyclopedia. Sage Publications, Thousand Oaks, 2012, 305.

12 Nagy Ferenc több írásában is jelzi, hogy a közérdekű munka bevezetésére Európában elsőként Lengyelországban került sor. (Lásd például NAGY Ferenc: Tanulmányok a Btk. Általános részének kodifikációjához. HVG-ORAC, Budapest, 2005, 256.) Lengyelországban valóban az 1969. évi Btk. (Kodeks Karny) vezeti be a munkabüntetéseknek ezt a formáját. A törvény 30. cikke 1. § értelmében a főbüntetések a szabadságvesztés, a szabadságkorlátozás és a pénzbüntetés. A 33. cikk 1-3. § értelmében a szabadságkorlátozás tartama három hónaptól két évig terjedhet, és ezen időszak alatt az elítélt a bíróság engedélye nélkül nem változtathatja meg lakóhelyét, elveszíti azt a jogát, hogy társadalmi szervezetekben funkciót töltsön be, és a mi szempontunkból a legfontosabb: köteles a bíróság által előírt munkát végezni. Lásd Európai szocialista országok büntető törvénykönyvei. Magyar Tudományos Akadémia Állam- és Jogtudományi Intézete, Budapest, 1973, 16-17. Érdekes módon azonban a téma lengyel ismertetői az időben később bevezetett angol modellt említik a most a lengyel Btk.-ban szereplő community service order előzményeként. (FRANKowSKI, Stanislaw: Polish Criminal Law. In: Frankowski, Stanislaw (ed.): Kluwer Introduction to Polish Law. Law International Hague, 2005, 360.) Tehát nem azt az eredeti formáját említi, amely inkább a javító-nevelő munka 1987-es magyar változatával egyezik meg.

13 Lásd HARDING, John: Forty Years of Community Service, http://www.theguardian.com/society/2013/jan/08/ forty-years-community-service (2017. 07. 05.). 
ségleteihez idomítva - apróbb-nagyobb különbségekkel. Ma már Európa összes országában megtalálható valamilyen formában.

A közérdekủ munka a köz érdekében végzett, a társadalom felé jóvátételi szándékkal teljesített ingyenes munkavégzés. ${ }^{14} \mathrm{Az}$ elítélt számára a közérdekủ munka végrehajtása során előny, hogy a közérdekümunka-büntetés alkalmazásával az elitélt elkerülheti a szabadságvesztést és annak káros következményeit, továbbra is a megszokott környezetében maradhat, otthonától, családjától sem elszakítva végezheti munkáját, ha van. A közérdekű munka szimbolikus jóvátételt jelent, azaz az elítélt jóvátétele nem közvetlenül a bűncselekmény sértettjét, hanem a társadalom egy részét, egy nagyobb közösséget célozza. A közérdekü munkát tehát mint büntetöjogi szankciót a szimbolikus jóvátétel egyik formájaként is említi a szakirodalom. ${ }^{15}$ Ezen szerzők abból a gondolatból indulnak ki, hogy a büncselekmény elkövetésével az elkövető egy kisebb vagy akár nagyobb közösséget, sőt a társadalom egészét sérti. A bűncselekmény ezáltal a közösségben félelemérzetet kelthet, romlik a közbiztonság, és ennek megfelelöen a közösségi béke helyreállitására van elsődlegesen szükség, mely nagyszerüen elérhető a közösség részére végzett munkával. Ezáltal a büncselekmény negatív következményeinek a szimbolikus jóvátételére kerül sor.

Ez a fajta jóvátétel jól alkalmazható azokra az esetekre is, amikor a búncselekménynek nincs konkrét sértettje, vagy annak kiléte nem állapítható meg, vagy éppen a büncselekmény áldozata nem kíván az elkövetővel találkozni és személyesen kiegyezni, vagyis mediációs eljárásban részt venni. Előfordul olyan eset is, amikor az elkövető valamilyen oknál fogva leggyakrabban rossz anyagi helyzete miatt nem képes anyagi jóvátétel adására. Ezekre az esetekre megoldás a közérdekü munka, melytöl remélhetöleg a közösség és az áldozat is elégedettebb lesz. ${ }^{16} \mathrm{~A}$ közérdekü munkát éppen ezért közösségi szankciónak is nevezik, melynek egyik lényegi eleme - sok más elem mellett - tehát a jóvátétel. ${ }^{17}$ Ennek megfelelően a közérdekü munka alternatív szankció abban az értelemben, hogy a szabadságvesztés helyett alkalmazható és elvileg maximálisan alkalmas is a végrehajtandó szabadságvesztés helyettesítésére, ugyanakkor a közösségi szankció lényegi ismérveivel is rendelkezik, különösen akkor, amikor a közösség valóban közremüködik az elkövetö reintegrációjában, és részt vesz a végrehajtásban. ${ }^{18}$

\section{A finn közérdekű munka}

Finnország a mindössze öt és félmilliós lakosságával nem tartozik a nagyobb európai államok közé. Történelme - hasonlóan a magyar történelemhez - inkább

14 GöRGÉnYı llona: A közérdekủ munka. In: Görgényi llona - Gula József - Horváth Tibor - Jacsó Judit - Lévay Miklós - Sántha Ferenc - Váradi Erika: Magyar Büntetőjog - Általános Rész. CompLex Kiadó, Budapest, 2012, 390.

15 Lásd NAGY Ferenc: Régi és új tendenciák a büntetöjogban és a büntetőjog-tudományban. Akadémiai Kiadó, Budapest, 2013, 149-150, GÖRgéNYl: i. m., 103-108.

16 GörgÉNYI: i. m., 104.

17 Lásd SIPos Ferenc: Munkával kapcsolatos szankciók a magyar büntetöjogban. PhD-értekezés, Debrecen, 2017, 69, http://jog.unideb.hu/documents/phd_sipos_2017_nyomtatni.pdf (2017. 07. 05.).

18 KEREZsI: i. m., 175. 
honvédő háborúkról és megszállásokról szól, sőt a kelet-európai államokhoz hasonlóan - bár azoknál lényegesen rövidebb ideig - szovjet megszállás alatt is állt a II. világháború után. A finn jogrendszer alapvetően nyugati gyökerekkel rendelkezik, de a szomszédos országok jogrendje is jelentős befolyást gyakorolt rá. ${ }^{19}$

A független finn igazságszolgáltatásnak egy jól áttekinthető, nem egészen százéves múltja van. Az igazságszolgáltatás rendszere, illetve a bírósági struktúra a körülbelül 800 éves svéd uralom évszázadai alatt fejlődött ki az 1809-ig tartó időszak során. 1809. március 29-én I. Sándor orosz cár uralma alá került az ország, és ettől az időponttól kapott Finnország viszonylagos önállóságot az Orosz Birodalmon belüli autonóm nagyhercegségként 1917 végéig. ${ }^{20} \mathrm{Az}$ országgyülés 1917. december 6-án független köztársaságnak kiáltotta ki Finnországot, ami a váltakozó intenzitású szovjet befolyási törekvések ellenére fönn is maradt gyakorlatilag napjainkig, de igazán nyugatorientált politikát Finnország csak a Szovjetunió 1991-es összeomlása után folytathatott. ${ }^{21}$

Az országot ma már egyebekben a skandináv államokhoz hasonló mutatók és számok jellemzik, mind a gazdasági és szociális, mind pedig a kriminológiai adatok tekintetében. Azonban ez a helyzet nemcsak a földrajzi fekvéséböl, klímájából vagy a közös kulturális hagyományokból ered, hanem föként egy tudatos és következetes stratégia eredménye. ${ }^{22}$ Manapság nehezen vitatható, hogy Finnországban müködik az egyik leghatékonyabb és leginkább elöremutató kriminálpolitika, nemcsak európai összehasonlításban, hanem az egész világon. Finnországban a pénzbüntetésben, a rövid tartamú büntetésekben, a nyitott börtönökben és a gondos rehabilitációban bíznak leginkább. Ennek is tulajdonítható, hogy a visszaesési mutatóik a legjobbak között vannak a világon. ${ }^{23}$

\section{A közérdekű munka története Finnországban}

Finnországban a börtönnépesség az 50 -es évek elején még kifejezetten magas volt, 200 fö körül alakult évente 100000 lakosonként, míg Dániában, Norvégiában és Svédországban körülbelül 50 fö volt ugyanez a szám. A négyszeres hátrányból induló finn igazságszolgáltatás átgondolt politikával kezdte csökkenteni a börtönnépességet. A közérdekú munka reformja csak az egyik, bár nagyon fontos tényező volt azok közül, melyek végül a finn büntetöpolitika irigylésre méltó eredményeit megalapozták.

A büntető anyagi jogot az 1889. december 1-jétöl hatályos, többször módosított 1889. évi Büntető Törvénykönyv tartalmazza. ${ }^{24} \mathrm{~A}$ módosítások túlnyomórészt a permanens enyhítés irányába hatnak a 20 . század második felétöl egészen napjainkig.

\footnotetext{
19 LAPPI-SePPÄLÄ, Tapio: Imprisonment and Penal Policy in Finland. Scandinavian Studies In Law, 2009/54, 335.

20 http://oikeusministerio.fi/en/index/theministry/historiaa.html (2016. 01. 03.). (Ez az oldal nem elérhető!)

Lásd Finnország története, http://finnugor.elte.hu/tortenelem/Egyesnepek/Finn/finntort.htm (2016. 01. 03.).

22 LAPPI-SeppäLÄ, Tapio: Criminology, Crime and Criminal Justice in Finland. European Journal of Criminology, 2012/2, 206.

23 Ikponwosa, O. Ekunwe-Jones, Richard S.: Finnish Criminal Policy: From Hard Time to Gentle Justice. The Journal of Prisoners on Prisons, 2012/1-2, 174

24 A továbbiakban: Finn Btk.
} 
Ez nemcsak a büntetések és az igazságszolgáltatás egészének szükséges humanizálódását jelenti, hanem tudatos és utilitarista elveken alapuló munka eredménye.

A folyamatos csökkenés ellenére még az 1970-es években is itt volt az egyik legmagasabb a bebörtönzöttek aránya, hiszen ebben az időszakban Nyugat-Európában is csökkenés volt megfigyelhető. Az 1970-es és 80 -as években, amikor a csökkenő trend a nyugat-európai országokban megfordul, a finn számok továbbra is csökkenést mutatnak, és az 1990-es évekre az ország elérte az északi államok átlagát. ${ }^{25} \mathrm{Az}$ 1970-es években végbemenő ítélkezési reform során Finnország létrehozott egy koherens, következetes egységet világos célokkal és következetes stratégiával. ${ }^{26} \mathrm{~A}$ következő táblázatban a legfontosabb lépéseket időrendben veszem sorra. A felsorolt rövid adatok ugyanakkor jól jelzik a követett irányt is.

1. táblázat. A finn büntetőpolitika változásainak legfontosabb állomásai²7

\begin{tabular}{|c|c|}
\hline 1950-es évek & A büntetések bírói enyhítésének bevezetése. \\
\hline 1966 & $\begin{array}{l}\text { A feltételes szabadságra bocsátás reformja. } 6 \text { hónapról } 4 \text { hónapra csökken } \\
\text { az időszak, ami után az elítélt feltételesen szabadságra bocsátható. }\end{array}$ \\
\hline 1967 & Amnesztia. Finnország függetlenségének 50. évfordulójára. \\
\hline 1969 & $\begin{array}{l}\text { A pénzbüntetés reformja. } \\
\text { A nyilvános részegség dekriminalizációja. } \\
\text { A személy elleni erőszak esetén a gondatlanul okozott sértő eredményért } \\
\text { a büntetések csökkentése. }\end{array}$ \\
\hline 1972 & $\begin{array}{l}\text { A lopásreform. A lopásért kiszabott büntetések csökkentése. } \\
\text { A kábítószerrel kapcsolatos büncselekmények büntetési tételének növelése. }\end{array}$ \\
\hline 1976 & $\begin{array}{l}\text { A feltételes szabadságra bocsátás reformja, a feltételes szabadságra } \\
\text { bocsátáshoz szükséges idő csökkentése } 4 \text { hónapról } 3 \text { hónapra. }\end{array}$ \\
\hline 1977 & $\begin{array}{l}\text { Az ittas vezetés reformja, pénzbüntetés és felfüggesztett szabadságvesztés } \\
\text { végrehajtandó szabadságvesztés helyett. } \\
\text { A pénzbüntetés mértékének emelése, hogy alkalmas legyen a szabadságvesz- } \\
\text { tés helyettesítésére. } \\
\text { A visszaesés jogkövetkezményeinek mérséklése. }\end{array}$ \\
\hline 1989 & $\begin{array}{l}\text { A feltételes szabadságra bocsátás reformja. } 3 \text { hónapról } 14 \text { napra csökken } \\
\text { az időszak, ami után az elítélt feltételesen szabadságra bocsátható. }\end{array}$ \\
\hline 1990 & Az előzetes letartóztatás idejének csökkentése. \\
\hline 1991 & $\begin{array}{l}\text { A tulajdon elleni büncselekmények büntetési tételeinek csökkentése. } \\
\text { A gazdasági bűncselekmények büntetési tétel növelése. }\end{array}$ \\
\hline 1992 & A közérdekű munka kísérleti bevezetése. \\
\hline
\end{tabular}

25 Lappl-SeppälÄ, Tapio: Penal Policy and Prisoner Rates in Scandinavia. In: Nuotio, Kimmo (ed.): Festschrift in Honour of Raimo Lahti. Faculty of Law, University of Helsinki, Helsinki, 2007, 265.

26 LAPPI-SeppäLÄ, Tapio: Imprisonment and Penal Policy in Finland. Scandinavian Studies In Law, 2009/54, 349-351.

27 Forrás: LAPPI-SePPÄLÄ, Tapio: Imprisonment and Penal Policy in Finland. Scandinavian Studies In Law, 2009/54. 
A közérdekű munka szerepe a börtönnépesség csökkentésében: a finn tapasztalatok

\begin{tabular}{|c|l|}
\hline 1993 & A kábítószerrel kapcsolatos büncselekmények büntetési tételének növelése. \\
\hline $1993-1995$ & A közérdekü munka kísérleti kiterjesztése az ország egész területére. \\
\hline 1996 & A közérdekű munka bevezetése a Btk.-ba. \\
\hline
\end{tabular}

Mint a fenti táblázatból látszik, a stratégia egyik eleme volt a közérdekű munka bevezetése is, amelyre 1992-ben került sor, ${ }^{28}$ nagyon átgondolt módon, elöször egy kísérleti időszakban ${ }^{29}$ csak az ország 12 vidéki körzetében és hat nagyvárosában volt alkalmazható, majd 1993-ban az egész ország területére kiterjesztették alkalmazását. ${ }^{30} \mathrm{~A}$ közérdekű munkát egészen 1996 decemberéig kísérleti jelleggel szabták ki, és csak amikor ez az időszak is sikerrel zárult, vált állandó elemévé a finn büntető törvénykönyvnek. ${ }^{31}$

A közérdekű munka bevezetésekor 20 és 200 óra közötti ingyenes munkavégzést jelentett a közösség számára, felügyelet mellett. ${ }^{32} \mathrm{~A}$ közérdekü munka bevezetésének a kezdetektől fő célja a rövid tartamú szabadságvesztés büntetések helyettesítése volt. Ezért maximum nyolc hónapig terjedő szabadságvesztés büntetés helyett volt kiszabható, de szigorúan csak abban az esetben, ha egyébként az ítélet végrehajtandó szabadságvesztés lett volna. ${ }^{33}$

A finn döntéshozók igyekeztek elkerülni azt a csapdát, hogy a börtönnépesség csökkentésére bevezetett alternatív büntetés végül ne a végrehajtandó szabadságvesztések számát, hanem más alternatív büntetések, például éppen a felfüggesztett büntetések vagy a próbára bocsátások számát csökkentse. ${ }^{34}$ Hogy a minél szélesebb körü használatát elősegítsék, illetve a kezdeti alkalmazáshoz segítséget nyújtsanak, a döntéshozók a finn bíróságoknál bevezettek egy kétlépcsős modellt, melyet a közérdekủ munka alkalmazása során volt kötelező használni. ${ }^{35}$

Az óvatos kezdő lépéseknek és a társadalmi elfogadottságnak, valamint a jól átgondolt kétlépcsős alkalmazási feltételeknek köszönhetően a közérdekü munka már a bevezetésétöl a szabadságvesztés valódi alternatívájává vált. Az alábbi táblázat jól mutatja, hogy a két büntetés a közérdekű munka bevezetésétől kezdve, minden

28 Act of 14 December 1990 (1990/1105).

29 1991. január 1. - 1993. december 31.

30 Act of 25 March 1994 (1994/227).

31 The Act of 12 December 1996 (1996/1055).

32 Joutsen, Matti-Lahtı, Raimo-Pölönen, Pasi: Criminal Justice Systems in Europe and North America. HeuniTammer-Paino Oy Tampere, Finland, 2001, 32.

33 Eley Susan-Mclvor Gill-Malloch Margaret-Munro William: A Comperative Review of Alternatives to Custody: Lessons from Finland, Sweden and Western Australia. Scottish Parliamentary Corporate Body, $2005,31$.

34 Más európai államokban megfigyelhető ez a hibás tendencia. Pradel arról számol be, hogy Franciaországban a közérdekủ munka a szabadságvesztés helyett inkább a pénzbüntetés alternatívájává vált. Lásd PRADEL, Jean: Community Service: The French Experience (From Community Service as an Alternative to the Prison Sentence). International Penal and Penitentiary Foundation, Bonn,1987, 32. Sajnos jelenleg ez a tendencia Magyarországon is megfigyelhető. A közérdekű munka alkalmazási gyakorisága jelentős emelkedést mutat az utóbbi években, de emellett a szabadságvesztés alkalmazási gyakorisága nem, ellenben a pénzbüntetés alkalmazási gyakorisága egyértelmü csökkenő tendenciát mutat. Lásd Bünözés és igazságszolgáltatás 2007-2015. Legföbb Ügyészség, Budapest, 2016, 3.

35 Lásd részletesen $A$ közérdekü munka hatályos szabályai cím alatt. 
évben hasonló, 9-11 ezer körüli számot mutat. Ahogyan nő a kiszabott közérdekümunka-büntetések száma, annak arányában a szabadságvesztések száma arányosan csökken.

2. táblázat. A közérdekümunka- és szabadságvesztés-büntetések aránya ${ }^{36}$

\begin{tabular}{|c|c|c|}
\hline & Szabadságvesztés & Közérdekű munka \\
\hline 1992 & 11,538 & 0 \\
\hline 1993 & 9,563 & 563 \\
\hline 1994 & 7,699 & 1,487 \\
\hline 1995 & 6,754 & 2,803 \\
\hline 1996 & 6,101 & 3,277 \\
\hline 1997 & 5,967 & 3,534 \\
\hline 1998 & 6,642 & 3,957 \\
\hline 1999 & 7,666 & 3,658 \\
\hline 2000 & 8,147 & 3,413 \\
\hline 2001 & 8,352 & 3,388 \\
\hline 2002 & 8,439 & 3,313 \\
\hline
\end{tabular}

A lenti ábrán pedig 1994-től kezdődően a szabadságvesztés-büntetések alakulását követhetjük nyomon, ahol látszik, hogy az 1999. évi megugrást követően a szabadságvesztés-büntetések száma tartósan magas marad, csúcsát 2004-ben éri el, aztán 2007-ben indul újfent csökkenésnek. Ez a csökkenő tendencia 2016-ban megfordulni látszik, ${ }^{37}$ de még nem világos, hogy a 2016-os növekedés egyedi eset vagy tendencia-e. A beszámolók szerint azonban a fő ok a nem finn elítéltek számának az ugrásszerü növekedése. ${ }^{38}$

36 Forrás: Statistics Finland (http://www.stat.fi/til/oik_en.html).

37 Lásd Criminal Sanctions Agency. Statistical Yearbook, 2016, http://www.rikosseuraamus.fi/material/attachments/rise/julkaisut-tilastollinenvuosikirja/oBJJPSYJI/RISE_Statistical_Yearbook_2016.pdf.

38 Lásd Criminal Sanctions Agency. Increase in Number of Prisoners After a Long Decline. 2017, http://www. rikosseuraamus.fi/en/index/topical/pressreleasesandnews/Pressreleasesandnews2017/03/increaseinnumb erofprisonersafteralongdecline.html. 


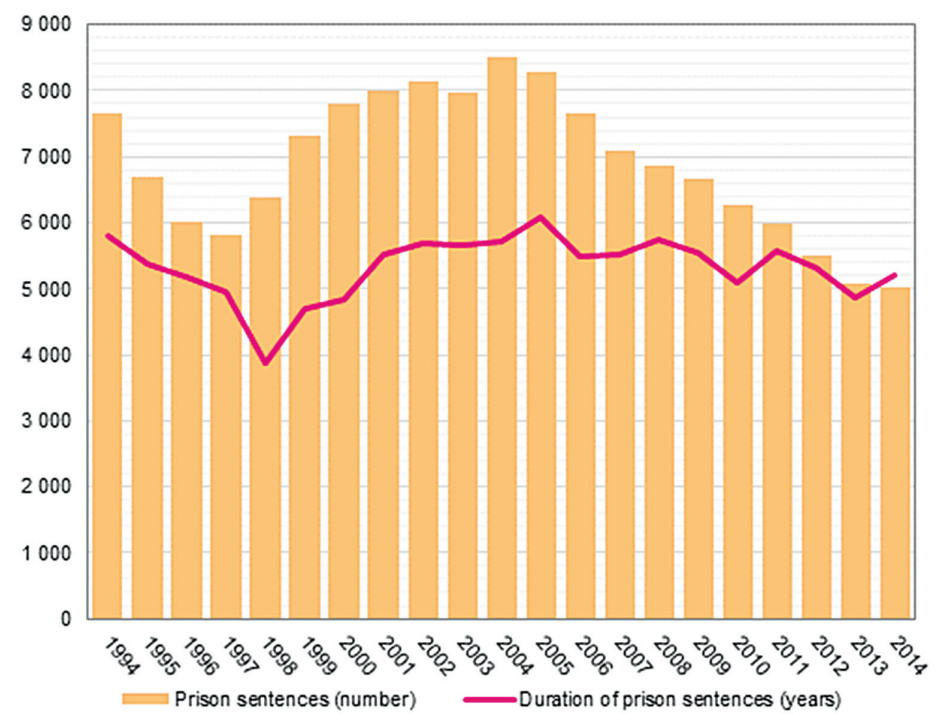

1. ábra. A szabadságvesztések számának és tartamának alakulása 1994 és 2014 között ${ }^{39}$

\section{A közérdekű munka hatályos szabályai}

A közérdekü munkára (yhdyskuntapalvelus) vonatkozó szabályozás a finn Btk. 6. és 7. fejezetében található. A 6. fejezet rendelkezik a büntetések kiszabásáról. A fejezet első szakaszában a jogszabály felsorolja a büntetéseket, melyeket a bíróság alkalmazhat. Ezek az egyösszegü és a napi tételes pénzbüntetés, a felfüggesztett szabadságvesztés, a közérdekủ munka, az elektronikus felügyelet és a végrehajtandó szabadságvesztés. ${ }^{40}$ Mint látható, nemzetközi összehasonlításban a finn büntetőjog viszonylag kevés szabadságvesztést helyettesítő alternatív eszközzel rendelkezik, azonban ezeket meglehetősen eredményesen alkalmazzák. ${ }^{41}$

A 6. fejezet 11. §-a értelmében azokat, akiket legfeljebb 8 hónap végrehajtandó szabadságvesztésre ítéltek, ehelyett közérdekű munkára lehet ítélni. Ha az elítéltet korábban már szabadságvesztésre vagy közérdekü munkára ítélték, vagy más súlyos indokok merülnek fel, például egy korábbi meghiúsult közérdekü munkára itélés, akkor a közérdekủ munka nem alkalmazható. Közérdekủ munkát csak akkor lehet alkalmazni, ha az elítélt ehhez előzetesen a beleegyezését adta, és a közérdekü munkát elöreláthatóan képes lesz elvégezni. Ha az elkövető a 21. életévét még nem töltötte be, mint fiatal felnőtt, több bizalmat, korának megfelelö munkát, szorosabb felügyeletet és rövidebb büntetést kap. ${ }^{42}$

\footnotetext{
39 Forrás: Statistics Finland, http://www.stat.fi/til/syyttr/2014/syyttr_2014_2015-09-30_tie_001_en.html.

40 Finn Btk. 6. fejezet 1 §, http://www.finlex.fi/en/laki/kaannokset/1889/en18890039.pdf.

41 LAPPI-SeppäLÄ, Tapio: Regulating the Prison Population: Experiences from a Long-term Policy in Finland. National Research Institute of Legal Policy, Helsinki, 1998, 26.

42 Finn Btk. 11. § (10.4.2015/401).
} 
A közérdekü munka kiegészítő büntetésként is alkalmazható. A finn Btk. értelmében a két évet meg nem haladó szabadságvesztés esetén van lehetőség annak végrehajtásában való felfüggesztésére. Felfüggesztett szabadságvesztés kiszabása esetén, ha az 8 hónap vagy azt meghaladó, a közérdekủ munka tartama 14 és 90 óra közötti tartamban szabható ki. ${ }^{43} \mathrm{~A} 8$. fejezet 11 . §-a szerint a közérdekú munka elévülésére ugyanazok a szabályok érvényesek, mint a szabadságvesztés-büntetés elévülésére. ${ }^{44}$

A közérdekủ munka minél gyakoribb alkalmazásának elösegítésére már a kezdetektöl bevezettek egy büntetéskiszabási protokollt, melynek lényege a következő.

Az első lépésben a bíróság egy elözetes döntést hoz, követve a büntetés kiszabására vonatkozó általános elveket és kritériumokat, elvileg itt még tekintet nélkül arra, hogy esetlegesen felmerülhet a közérdekü munka kiszabásának lehetősége is. Abban az esetben, ha az első lépés eredménye az, hogy az általános büntetéskiszabási gyakorlat szerint végrehajtandó szabadságvesztést kellene kiszabni, a bíróság e helyett közérdekű munkát alkalmazhat, de kizárólag akkor, ha az alábbi három feltétel is teljesül egyidejüleg.

A második lépés első feltétele a kényszermunka tilalmára tekintettel, hogy az elkövető elözetesen és kifejezetten hozzájáruljon ahhoz, hogy ezt a szankciót alkalmazzák vele szemben. A második lépés második feltétele, hogy a bíróság szerint az elkövető, tekintettel az általános testi és szellemi állapotára, elöreláthatóan képes legyen eleget tenni az ítéletben meghatározott munkakötelezettségnek. A harmadik pedig, hogy ne legyen visszaeső vagy büntetett elöéletü. Ebben az esetben ugyanis a bíróság nem függesztheti fel a kiszabott szabadságvesztés-büntetés végrehajtását.

Néhány más országhoz hasonlóan Finnországban is szükség van egy pártfogó felügyelői véleményre..$^{45}$ Ezek a vélemények tartalmazzák a terhelt előzetes beleegyező nyilatkozatát is. Lappi-Seppälä szerint sajnálatos, hogy a legtöbb országban a beleegyezés egy formális aktussá degradálódik, célja és feladata mindösszesen annyi, hogy a kényszer- és kötelező munka tilalmába ütközést elkerülje az ítélet. Finnországban ezzel szemben a beleegyezést részletes tájékoztatás előzi meg, és Lappi-Seppälä szerint a terhelt kifejezett előzetes egyetértése a legbiztosabb záloga annak, hogy a végrehajtás várhatóan sikeres lesz. ${ }^{46}$

A közérdekű munkát bevezetésekor 20-200 óra közötti tartamban lehetett kiszabni. A finn közérdekủ munka tartama 2015 januárjától megváltozott. Mind az alsó, mind pedig a felső határa a nagyobb jogalkalmazói szabadság irányába mozdult el.

${ }^{43}$ Lásd Criminal Sanctions Agency: Avonvankila. Öppet fängelse, Open Prisons. http://www.rikosseuraamus.fi/ material/attachments/rise/esitteetenglanti/leIQUMTG5/CRIMINAL_SANCTIONS_AGENCY_BROCHURE_ A4.pdf (2016. 03. 03).

44 Finn Btk. 11. § (4.2003/297).

45 Ilyen vélemény beszerzését követeli meg például a cseh, a dán, a svéd és az angol szabályozás is. Bövebben a beleegyezés kérdéséröl: Sipos Ferenc: A kényszermunka tilalma és a beleegyezés kérdése a közérdekümunka-büntetés kapcsán. Magyar Jog, 2017/1, 33-37.

46 LAPPI-SEPPÄLÄ, Tapio: Techniques in Enhancing Community-Based Alternatives to Incarceration: A European Perspective. In: United Nations Asia and Far East Institute for the Prevention of Crime and Treatment of Offenders. Tokyo, Japan. Annual Report for 2002 and Resource Material Series No. 61. NY: United Nations Publications, New York, 2003, 73 [a továbbiakban: LAPPI-SEPPÄLÄ (2003)]. 
Az alsó határ 14 órára csökkent, míg a felső határa 240 órára nőtt. ${ }^{47} \mathrm{~A}$ szabadságvesztés átváltása egy az egyhez arányban történik, bár ez az arányosság nagyon barátságos, hiszen egy nap szabadságvesztés egyórányi közérdekü munkának felel meg, ami kifejezetten kedvezőnek tünik az elítélt számára. Tehát a szabadságvesztés tartama a közérdekủ munka hosszától függ.

A kritikusokat, akik szerint az, hogy a tulajdonképpen a szabadságvesztésre ítélt elítélt egy óra munkával egy nap szabadságvesztést teljesít, túlságosan enyhének itélik, talán megnyugtathatja, hogy a közérdekü munkából nincs mód a feltételes szabadságra bocsátásra, azaz ebben az esetben az elítélt teljes egészében letölti a büntetését, míg a szabadságvesztés esetén a büntetés felének kitöltését követően szabadon bocsátható. ${ }^{48}$

A közérdekű munka Finnországban csak munkakötelezettséget jelent és a hátrányai annak időtartamára korlátozódnak, és nem jár együtt extra felügyelettel. Azaz a közérdekủ munka végrehajtása során a meglehetősen szoros felügyelet csak a munkavégzés idejére terjed ki, és nem tartalmaz kontrollelemeket az elítélt munkán kívüli magatartására, ellentétben más skandináv államokkal, ahol ez jellemző. Kimondható tehát, hogy a felügyelet a közérdekủ munkához szorosan kötődő és nem önálló eleme a közérdekủ munkának. ${ }^{99}$

Abban az esetben, ha az elítélt a munkakötelezettségének önként nem tesz eleget, az esetek túlnyomó részében új eljárásban, végrehajtandó szabadságvesztésre ítélik. ${ }^{50} \mathrm{~A}$ kisebb fokú szabályszegések esetén egyszerūen megrovásban részesül az elítélt, a komolyabb, súlyosabb szabályszegést jelentő ügyekben azonban értesítik az ügyészt, aki jogosult bíróság elé vinni az ügyet. Ha a bíróság úgy találja, hogy a szabályszegés súlyos, a fennmaradó órákat átváltoztatja végrehajtandó szabadságvesztésre, a már ledolgozott órákat azonban le kell vonnia. ${ }^{51}$

Az elítélt, akit közérdekü munkára ítéltek, egy elöre meghatározott terv szerint tesz eleget az ítéletben foglaltaknak. A tervet jóvá kell hagynia a végrehajtásért felelös ügynökségnek is.$^{52} \mathrm{~A}$ tervet az elítélt bevonásával készítik el, mely tartalmazza a munka végrehajtásának részleteit, amelyet aztán az elítélt köteles pontról pontra követni.

A közérdekủ munka elsősorban az állami szektorban, pontosabban állami, önkormányzati, önkormányzati-hatósági intézményben végezhető. Teljesíthető továbbá egyháznál, köztestületeknél vagy egyéb nonprofit szervezetnél (egyesület, sportklub, alapítvány). Tilos viszont nyereségorientált cégeknél vagy magánvállalkozásoknál végezni. A kijelölt munkahelyek nem kapnak anyagi támogatást, a nyilvánvaló közösségi-társadalmi hasznosságukon túl a közvetlen hasznuk az ingyenesen végzett munka.

47 400/2015 törvény 8. fejezet 37. §.

48 LAPPI-SEPPÄLÄ (2003): i. m., 74.

49 LAPPI-SEPPÄLÄ (2003): i. m., 75.

50 Eley Susan-Mclvor Gill-Malloch Margaret-Munro William: A Comperative Review of Alternatives to Custody: Lessons from Finland, Sweden and Western Australia. Scottish Parliamentary Corporate Body, 2005, 32-33.

51 LAPPI-SEPPÄLÄ: (2003): i. m., 75.

52 A úgynevezett Büntetés Végrehajtási Ügynökség látja el ezt a feladatot. 
A közérdekủ munka általában kisegítő tevékenységet, könnyű fizikai munkát jelent. A leggyakoribb feladatok például az ingatlan-karbantartás vagy konyhai munka önkormányzati intézményekben, illetve ápolási otthonokban, kórházakban és egészségügyi központokban. Az egyházak részére végzett közérdekủ munka gyakran temetőtakarításból és karbantartási feladatokból áll.

A végrehajtásra vonatkozó terv egy alkalomra általában 3-4 óra munkát határoz meg, heti kétszer. Az elítélt utazással kapcsolatos költségeit a munkahely viseli. A munkahelyen egy kijelölt személy végzi az elítélt felügyeletét, és ő tartja a kapcsolatot az ügynökséggel is. Finnországban hozzávetöleg 2600 végrehajtó munkahely van, erre a listára fölkerülni önkéntes jelentkezéssel lehet. ${ }^{53}$

\section{A közérdekű munka alkalmazása, gyakorlata Finnországban}

Az 1998-99-es időszakban elért csúcs után a közérdekủ munka alkalmazása némileg csökkent, ${ }^{54}$ majd ezt követően lassú növekedésnek indult. Az átlagos egy napra lebontott közérdekü munka büntetések száma a 2000-es években 15\%-kal nőtt. Az újabb csúcsát 2007-ben érte el napi 4800 fővel, azóta az alkalmazásának mértéke folyamatosan csökken. 2014-ben a napi átlag már csak 3137, ami 35\%-os csökkenést jelent a 2007-es esztendöhöz képest. 2015-ben és 2016-ban a csökkenés folytatódik. 2016-ban 8\%-kal kevesebb fö tölt közérdekűmunka-büntetést, mint 2015-ben.

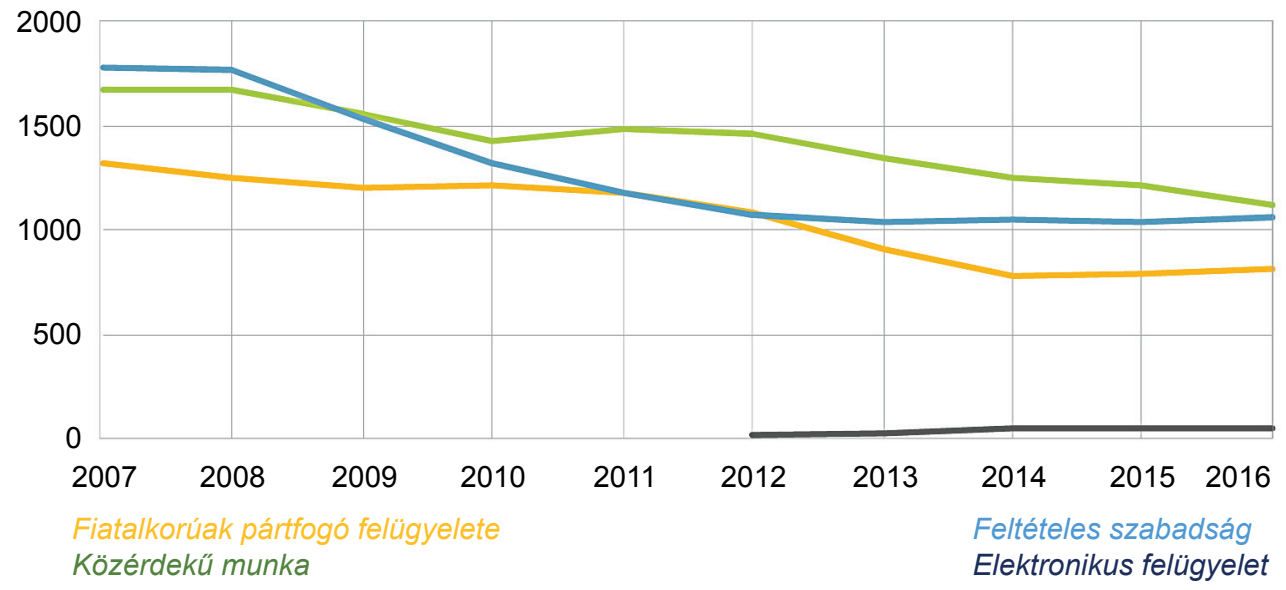

2. ábra. A közérdekü munka alkalmazásának mértéke ${ }^{55}$

53 Lásd Criminal Sanctions Agency. Sentences and Statutes, http://www.rikosseuraamus.fi/text/en/index/ sentences/communitysanctions/communityservice/carryingouttheservice.html (2015. 12. 30.).

54 Eley Susan-Mclvor Gill-Malloch Margaret-Munro William: i. m., 34.

55 Forrás: Criminal Sanctions Agency. Statistical Yearbook, 2016, http://www.rikosseuraamus.fi/material/ attachments/rise/julkaisut-tilastollinenvuosikirja/oBJJPSYJI/RISE_Statistical_Yearbook_2016.pdf. 
A közérdekủ munka alkalmazásában való visszaesés nem drámai mértékủ az elmúlt 25 év során, és a témával foglalkozó finn büntetőjogászok szerint teljesen természetes és logikus válasz a megelőző gyors emelkedésre. ${ }^{56}$ Ez érdekes példa lehet Magyarország számára is, ahol az elmúlt években szintén kiugró értékeket produkál a közérdekümunka-büntetés alkalmazásának aránya, majdnem elérve a kiszabott büntetések $25 \%$-át.

A közérdekủ munka remek alternatívát kínál a közlekedési bủncselekmények elkövetőinek szankcionálására, és Finnországban erre szükség is van. Finnországban ugyanis rendkívül magas - nemcsak Európában, de talán a világon is a legmagasabb - a közlekedési büncselekmények, ezen belül az ittas vezetések száma. A különböző országok között meglehetősen széles szórást mutatnak a statisztikák, de akkor is megdöbbentő, hogy míg Angliában és Walesben vagy éppen Örményországban 100000 lakosonként kevesebb mint hét esetet regisztrálnak évente, addig ugyanez a szám Finnország esetén több mint $2000 .{ }^{57} \mathrm{~A}$ finn bíróságok a felfüggesztett ítéletek több mint felét ittas vezetésért szabják ki, továbbá jellemző, hogy az ittas vezetésért kiszabott ítéletek fele szabadságvesztés. Összehasonlításképpen Svédországban mindössze az összes elítélt harmada kerül börtönbe ittas vezetésért, míg az alacsonyabb kockázatú bünelkövetők jellemzően inkább próbára bocsátást és föként elektronikus nyomkövetöt vagy közérdekümunka-büntetést kapnak. ${ }^{58}$

3. táblázat. A közösségi büntetések napi számának alakulása 2005-2014 években ${ }^{59}$

\begin{tabular}{|c|c|c|c|c|c|c|}
\hline & $\begin{array}{c}\text { Feltételesen } \\
\text { elítélt fiatal- } \\
\text { korúak } \\
\text { pártfogó } \\
\text { felügyelete }\end{array}$ & $\begin{array}{l}\text { Fiatalkorúak } \\
\text { büntetése }\end{array}$ & $\begin{array}{l}\text { Közérdekü } \\
\text { munka }\end{array}$ & $\begin{array}{c}\text { Feltételes } \\
\text { szabadságon } \\
\text { lévő elítéltek } \\
\text { pártfogó } \\
\text { felügyelete }\end{array}$ & $\begin{array}{l}\text { Elektronikus } \\
\text { nyomkövető }\end{array}$ & Összes \\
\hline 2005 & 1572 & 30 & 1752 & 1437 & - & 4791 \\
\hline 2006 & 1428 & 28 & 1650 & 1486 & - & 4593 \\
\hline 2007 & 1326 & 17 & 1672 & 1785 & - & 4800 \\
\hline 2008 & 1246 & 15 & 1679 & 1772 & - & 4713 \\
\hline 2009 & 1208 & 10 & 1559 & 1532 & - & 4307 \\
\hline 2010 & 1214 & 12 & 1428 & 1316 & - & 3970 \\
\hline 2011 & 1178 & 14 & 1490 & 1177 & - & 3859 \\
\hline 2012 & 1084 & 10 & 1458 & 1074 & 18 & 3645 \\
\hline 2013 & 908 & 7 & 1344 & 1036 & 29 & 3324 \\
\hline 2014 & 781 & 10 & 1247 & 1054 & 45 & 3137 \\
\hline
\end{tabular}

56 Eley Susan-Mclvor Gill-Malloch Margaret-MunRo William: i. m., 42.

57 Lásd European Sourcebook of Crime and Criminal Justice Statistics 2014. Heuni, Helsinki, 2014, 150.

58 Kristofferson, Ragnar: Correctional Statistics of Denmark, Finland, Iceland, Norway and Sweden 20012005. Correctional Service of Norway Staff Academy, Oslo, 2007, 171.

59 Lásd SıPos Ferenc: Munkával kapcsolatos szankciók a magyar büntetőjogban. Doktori értekezés, 2017, http://www.stat.fi/til/syyttr/2014/syyttr_2014_2015-09-30_tie_001_en.html. 
A végrehajtandó szabadságvesztések közel 36 százalékát helyettesítette közérdekü munka 2014-ben. ${ }^{60} \mathrm{~A}$ közérdekümunka-büntetéseket elsősorban ittas vezetés, másodsorban vagyon elleni büncselekmények, majd főként testi sértés miatt alkalmazzák.

\section{$2009 \square 2011 \square 2013 \square 2016$}

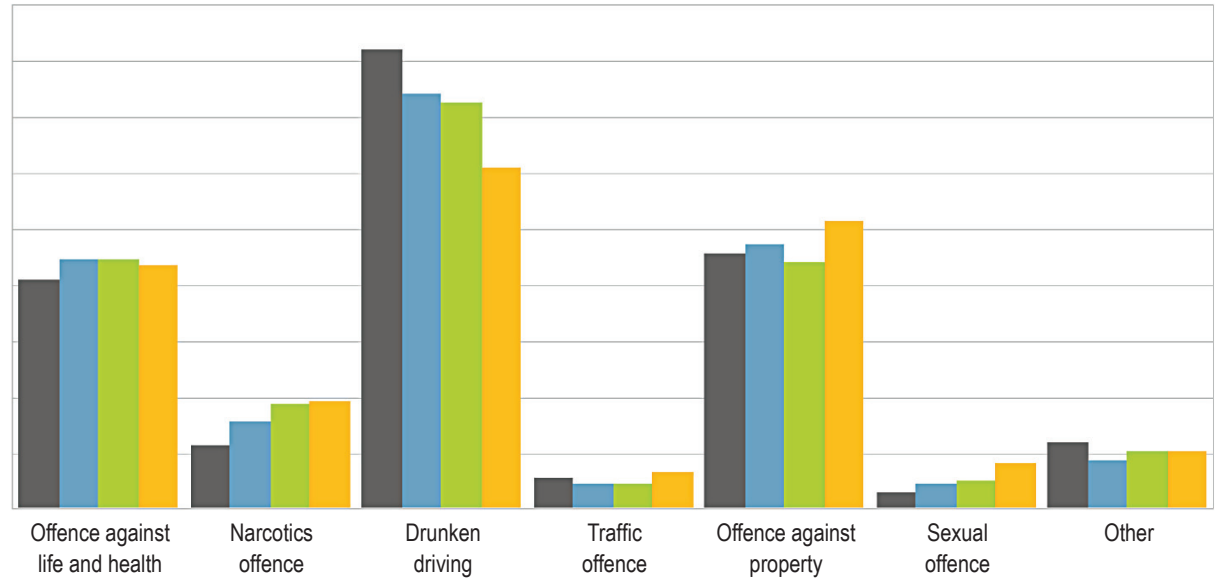

3. ábra ${ }^{61}$

A 35\%-os visszaesési arányával Finnország az egyik legjobb eredményeket felmutató ország a világon. Ez több tényre is visszavezethető, de a legjelentősebb ezek közül a döntéshozóknak, a témával foglalkozó kutatóknak és a gyakorlati szakembereknek az a közös meggyőződése volt, hogy a kezdetben kimagasló börtönpopuláció léte szégyen volt Finnországra nézve, és ezért (is) mindent megtettek, ami hatalmukban állt, hogy azt csökkentsék. A szakmai együttmüködés eredménye pedig nemcsak az alacsony börtönpopuláció, hanem az alacsony visszaesési ráta is. ${ }^{62}$

A finnek bíznak a közérdekümunka-büntetésben, általános a vélekedés, hogy mindenki megérdemel egy második esélyt. Népszerủ büntetés a gazdaságossága miatt is. Az átlagos költsége a végrehajtandó szabadságvesztéseknek éves költséget alapul véve Finnországban 71000 euró körül alakul, ugyanez a költség a közösségi büntetések esetén hasonló időszakra vetítve 5000 eurót tesz ki. ${ }^{63}$

60 Lásd Sipos Ferenc: i. m., http://www.stat.fi/til/syyttr/2014/syyttr_2014_2015-09-30_tie_001_en.html.

61 Criminal Sanctions Agency. Statistical Yearbook, 2016, http://www.rikosseuraamus.fi/material/attachments/ rise/julkaisut-tilastollinenvuosikirja/oBJJPSYJI/RISE_Statistical_Yearbook_2016.pdf.

62 EKunwe, Ikponwosa O.-Jones, S. Richard: i. m., 181.

63 Henriksson, Anna-Maja, Minister of Justice of Finland at the $19^{\text {th }}$ Council of Europe, Conference of Directors of Prison and Probation Services on 17 June 2014, Helsinki. 
4. táblázat. A közösségi büntetések napi számának alakulása 2005-2016 években ${ }^{64}$

\begin{tabular}{|c|c|c|c|c|c|c|}
\hline & $\begin{array}{c}\text { Feltételesen } \\
\text { elítélt fiatal- } \\
\text { korúak } \\
\text { pártfogó } \\
\text { felügyelete }\end{array}$ & Fiatalkorúak & $\begin{array}{c}\text { Közérdekü } \\
\text { munka }\end{array}$ & $\begin{array}{c}\text { Feltételes } \\
\text { szabadságon } \\
\text { lévő elítéltek }\end{array}$ & $\begin{array}{c}\text { Elektronikus } \\
\text { nyomkövető }\end{array}$ & Összes \\
\hline 2005 & 1572 & 30 & 1752 & 1437 & - & 4791 \\
\hline 2006 & 1428 & 28 & 1650 & 1486 & - & 4593 \\
\hline 2007 & 1326 & 17 & 1672 & 1785 & - & 4800 \\
\hline 2008 & 1246 & 15 & 1679 & 1772 & - & 4713 \\
\hline 2009 & 1208 & 10 & 1559 & 1532 & - & 4307 \\
\hline 2010 & 1214 & 12 & 1428 & 1316 & - & 3970 \\
\hline 2011 & 1178 & 14 & 1490 & 1177 & - & 3859 \\
\hline 2012 & 1084 & 10 & 1458 & 1074 & 18 & 3645 \\
\hline 2013 & 908 & 7 & 1344 & 1036 & 29 & 3324 \\
\hline 2014 & 781 & 10 & 1247 & 1054 & 45 & 3137 \\
\hline 2015 & 786 & 9 & 1217 & 1033 & 48 & 3093 \\
\hline 2016 & 819 & 9 & 1120 & 1067 & 47 & 3061 \\
\hline
\end{tabular}

\section{Zárógondolatok}

A közérdekű munka szabályozása Európában számos nemzetközi dokumentumra van tekintettel. Bármelyik európai állam hatályos szabályozását vizsgáljuk is, elmondható, hogy az egyezések elsősorban a közös szabályelemekre vezethetőek vissza, az apróbb különbségek, melyek elsősorban a kiszabásban és a végrehajtás módjában jelentkeznek, teszik egyedivé az adott állam szabályozását.

A finn büntetőjog nagyszerüen bizonyítja, hogy az alternatív vagy közösségi szankciók alkalmazási gyakorisága és hatékonysága egyáltalán nem attól függ, hogy a jogalkotó milyen gazdag szabadságvesztést helyettesítő szankciólistát kínál a bírák számára. Hiszen láttuk, hogy meglepően kevés a finn bíró által választható alternatív szankciók száma, mégis az összes kiszabott büntetésből nagy aránnyal szerepelnek az alternatív büntetések.

A finn közérdekủ munka egy átgondolt stratégia részeként, felkészülési időszakot biztosító sajátos skandináv kísérleti szakasz után került bevezetésre. Magyarországon sajnos erre a közérdekű munka bevezetésekor nem volt lehetőség, így nem volt lehetőség a tapasztalatszerzésre sem. ${ }^{65}$ Így aztán elkövettük azt a hibát, hogy bevezetésekor hiányoztak azok a pénzügyi, technikai és infrastrukturális feltételek, amelyek sikeres alkalmazásához elengedhetetlenek lettek volna.

64 Lásd Statistics of the Criminal Sanctions Agency, 2014, http://www.rikosseuraamus.fi/material/attachments/ rise/julkaisut-tilastollinenvuosikirja/bCNzCZ22h/Statistical_Yearbook_2014_of_the_Criminal_Sanctions Agency_korjattu.pdfés http://www.rikosseuraamus.fi/material/attachments/rise/julkaisut-tilastollinenvuosikirja/ oBJJPSYJI/RISE_Statistical_Yearbook_2016.pdf.

65 Kerezsi: i. m., 171. 
Összességében elmondható, hogy a közérdekủ munka alkalmazásának sikere és eredményessége a megfelelöen tervezett és végigvitt bevezetésen és a jól szervezett, gondosan ellenőrzött, infrastrukturálisan és financiálisan jól ellátott végrehajtáson múlik. ${ }^{66} \mathrm{Ha}$ a végrehajtásra megfelelő energia, figyelem és szükséges anyagi ráfordítás jut, az eszközök rendelkezésre állnak, a jogintézmény jól müködik, míg hiába a szépen cizellált, körültekintően összeállított, mindenre tekintettel lévő szabályozás, ha a végrehajtás nem megfelelő, a büntetés nem lesz eredményes. A közérdekű munka hatékony végrehajtása még várat magára Magyarországon.

Finnország azonkívül, hogy tudatosan szervezett, átgondolt büntetőpolitika részeként vezette be a közérdekű munkát, arra is figyelemmel volt, hogy a közérdekü munka alkalmazása során ne essenek abba a tipikus hibába, hogy a közérdekủ munka valóban a szabadságvesztés és ne más alternatív büntetés helyettesítésére szolgáljon.

Figyelemre méltó továbbá Finnországban az is, hogy a finnek bíznak az igazságszolgáltatásban, és hisznek az alternatív szankciók eredményességében. E tekintetben is van mit tanulni tölük. Magyarországon a társadalomban mindenképpen tudatosítani kellene e büntetési nem előnyeit, hangsúlyozva elsősorban a szabadságvesztéshez képest meglévő többletértékeket, a benne rejlő reintegrációs lehetőségeket, az értékteremtő jellegét, valamint a büntetés gazdaságos voltát.

Mindenképpen indokolt lenne egy, a közérdekű munka előnyeit bemutató társadalmi kampány hazánkban, hogy a társadalom tagjaiban tudatosodjon, hogy ennek a büntetésnek az eredményes végrehajtásához nagyon sok társadalmi aktivitás szükséges. A kampány feladata lenne továbbá az is, hogy növelje a rendelkezésre álló és a büntetési célok eléréséhez minél jobban illeszkedő letöltő helyek számát. Mert bár igaz, hogy ma hazánkban, ha nincs a meghatározott feltételeknek megfelelő más munkahely, a helyi önkormányzati költségvetési szervek vagy ezek intézményei, a helyi közszolgáltatást végző egyéb szervezetek, az önkormányzati tulajdon kezelésével és fenntartásával megbízott vagy erre a célra az önkormányzat által létrehozott gazdálkodó szervezetek kötelesek a közérdekű munkavégzés helyét biztosítani. Mégis szükség lenne a büntetés társadalmi céljainak eléréséhez, hogy minél nagyobb társadalmi aktivitás mutatkozzon a végrehajtásban, hogy a közérdekü munka valódi közösségi büntetéssé válhasson.

\section{Abstract}

A major part of the endeavours in recent punitive policy is to find alternatives for imprisonment. By a well-thought-out application of alternative sanctions and especially community work, criminal policy may greatly affect the proportion of the imposed sentences of imprisonment. One of the good examples can be seen in Finland, where the prison population of 200 convict per 100.000 citizens could be decreased to the quarter in a few decades. This study endeavours to present this process, hoping that such a short review may be usefully edifying also for Hungarian criminal policy.

66 KELEMEN Ágnes: A Community Service - közérdekủ munkavégzés - büntetés angliai tapasztalatairól. Magyar Jog, 1989/1., 74-79. 